\title{
INFLUENCE OF SCENIC ROAD CORRIDOR ON PLANT DIVERSITY IN KUNYU MOUNTAIN, CHINA
}

\author{
YIN, X. D. ${ }^{1,2}-$ GAO, Y. ${ }^{1,3^{*}}-$ LIU, J. ${ }^{4}-$ ZHAO, W. G. ${ }^{3}$ \\ ${ }^{1}$ Shandong Provincial Key Laboratory of Water and Soil Conservation and Environmental \\ Protection, College of Resources and Environment, Linyi University \\ Linyi 276005, China \\ ${ }^{2}$ Linyi NO.1 High School of Shandong Province \\ Linyi 276000, China \\ (e-mail: yinxiaodi0717@126.com) \\ ${ }^{3}$ Linyi Scientific Exploration Laboratory \\ Linyi 276037, China \\ (e-mail:1396870345@qq.com) \\ ${ }^{4}$ College of Biological Sciences and Biotechnology, Beijing Forestry University \\ Beijing 100083, China \\ (e-mail: liujian20170703@163.com) \\ *Corresponding author \\ e-mail: gaoyuan1182@tom.com,gaoy@lyu.edu.cn \\ (Received $18^{\text {th }}$ Nov 2017; accepted $12^{\text {th }}$ Feb 2018)
}

\begin{abstract}
The edge effect of forest communities in Kunyu Mountain Nature Reserve of China due to two small-scale roads was studied. By setting 3 groups of sample plots: sample plot beside $2.5 \mathrm{~m}$ road corridor, sample plot beside $5.0 \mathrm{~m}$ road corridor and sample plot in wildwood area, forest investigation was carried out using typical sampling method to evaluate and reveal the influence of edge effect (caused by $2.5 \mathrm{~m}$ and $5.0 \mathrm{~m}$ scenic road corridor) on the community structure, species composition and diversity of plants in Kunyu mountain national nature reserve. Results show (1) that compared with wildwood area, the average $D B H$ (diameter at breast height) of tree layer at $2.5 \mathrm{~m}$ and $5.0 \mathrm{~m}$ scenic road corridor in Kunyu mountain national nature reserve decreases with the increase of width of road corridor. In shrub layer, edge effect is balanced by increasing the number of low-diameter shrubs while decreasing the number of high-diameter shrubs. It is worth noting that the edge effect of $2.5 \mathrm{~m}$ scenic road corridor is significantly higher than that of $5.0 \mathrm{~m}$ scenic road corridor. (2) In tree layer, the four indexes all showed as follows: sample plot near $5.0 \mathrm{~m}$ scenic road corridor was significantly higher than the sample plot near $2.5 \mathrm{~m}$ scenic road corridor and wildwood area. In shrub layer, the four indexes abovementioned can be ranked as sample plot near $5.0 \mathrm{~m}$ scenic road corridor>sample plot near $2.5 \mathrm{~m}$ scenic road corridor>wildwood area. In herb layer, the 4 indexes are ranked as sample plot near $5.0 \mathrm{~m}$ scenic road corridor>wildwood area>sample plot near $2.5 \mathrm{~m}$ scenic road corridor. Main conclusion: The $2.5 \mathrm{~m}$ scenic road corridor exerts an inhibition effect on the species composition and diversity of plants in Kunyu mountain national nature reserve, however, $5.0 \mathrm{~m}$ scenic road corridor has a promoting effect.
\end{abstract}

Keywords: channel corridor, edge effect, species composition, plant diversity, Kunyu Mountain National Nature Reserve

\section{Introduction}

Frequent human activities lead to habitat fragmentation and loss of species diversity. Under such background, continuous natural habitat is gradually replaced by fragmentated forest patches and the forest edge area is gradually increased (Lian and Yu, 2000; Velázquez et al., 2017). Corridor refers to linear or banded landscape element 
which is different from surrounding landscape matrix (Zhu et al., 2005; Naidoo et al., 2018). Corridor can lead to change of ecological factors, thus making system components and behaviors (i.e. Population density, productivity and diversity, etc.) different from that inside of system (Wang and Ma, 1985; Chen et al., 2004). Road exists as corridor of landscape. The introduction of road enhances the fragmentation degree of landscape and the influencing area of edge effect (Zhou et al., 2009). Studies show that the edge effect of corridor causes the inhomogeneous distribution of species composition and diversity between inside and outside of plants community; The positive and negative edge effects are correlated with the area, shape, forming age, connectivity of forest patches as well as the property of neighboring patches. Therefore, research results on the positive and negative corridor edge effects are quite different (Sun et al., 2008; Wu et al., 2011; Liu et al., 2012). In fragmented forest patches, environmental factors such as solar irradiance, humidity and soil are normally in graded distribution from forest edge to inner forest. Therefore, the distance between inner patch to forest edge is correlated with corridor edge effect. The species composition, community structure and diversity also vary from forest edge to inner forest (Ma et al., 2008; Su et al., 2014). Since different plants have different sensitivities to habitat fragmentation, they have different strategies to get adapted to environmental change. For example, sensitive vs. tolerant species, trees vs. shrubs, shade-tolerance species vs. shade-intolerance species, evergreen species vs. deciduous species, they have different responses to edge effect; therefore, research results on corridor edge effect are different (Tian et al., 2011).

Studying the edge-induced community-based effects helps to understand the ecosystem changes caused by the road network, which may break the ecosystem integrity through the marginal effects of microclimates (García et al., 2007). The study of action characters of edge effect of scenic road corridor can provide data reference and theoretical basis for biodiversity conservation, balance of travel activities, and construction planning of future scenic road. In this paper, based on scenic road corridor of Kunyu mountain nature reserve as research objects, the property and action characters of edge effect of scenic road corridor were analyzed, in the hope of figuring out how the edge effect of scenic road corridor $(2.5 \mathrm{~m}$ and $5.0 \mathrm{~m})$ will affect the plants community structure, species composition and diversity.

\section{Materials and methods}

\section{Profile of research area}

Kunyu mountain national nature reserve locates at eastern shandong province, China, with geographical coordinates of $37^{\circ} 16^{\prime}-37^{\circ} 25^{\prime} \mathrm{N}, 121^{\circ} 42^{\prime}-121^{\circ} 50^{\prime} \mathrm{E}$. It is the native place of Chinese red pine (Pinus densiflora) and the world's largest distribution of red pine (Pinus densiflora) forest, the best protected natural distribution center. It is one of the most biodiversity-rich regions in the world at the same latitude. It is the only place in the world to study the location of forest ecosystems for the project "Natural Control of Forest Pests". Kunyu mountain national nature reserve covers area of $48 \mathrm{~km}^{2}$, with the main peak-Taibo Peak reaching an altitude of $923 \mathrm{~m}$. The soil of Kunyu mountain nature reserve is mainly brown soil, which has a sandy texture, in acidic to slightly acidic condition. The climate here belongs to warm temperate continental monsoon climate, with four distinctive seasons, abundant sunlight, annual mean temperature at $11.9{ }^{\circ} \mathrm{C}$ and annual rainfall of $985 \mathrm{~mm}$. Kunyu mountain national nature reserve is national forest park 
and national 4A tourist scenic area. The forest coverage rate is about $92 \%$, mainly consisting of red pine (Pinus densiflora), black pine (Pinus thunbergii), oak (Quercus acutissima) and locust (Robinia pseudoacacia) (Du et al., 2007).

\section{Research method}

\section{Field investigation}

Through reviewing literatures, inquiring forest management department and field investigation, forest investigation was carried out using typical sampling method (Fang et al., 2004; Fang et al., 2009). The investigation results show that the plant community was in natural growth and succession condition, i.e. indicating half-mature forest. The sample plot dimension was $20 \mathrm{~m} \times 30 \mathrm{~m}$. Three different sample plots were set, including sample plot near $2.5 \mathrm{~m}$ scenic road corridor, sample plot near $5.0 \mathrm{~m}$ scenic road corridor and sample plot at wildwood area. Five repeated investigations were conducted in each sample plot.

Investigations of plant species diversity were carried out in tree layer, shrub layer and herb layer. The research areas included one tree layer of $20 \mathrm{~m} \times 30 \mathrm{~m}, 1$ shrub layer of $10 \mathrm{~m} \times 10 \mathrm{~m}$ and 4 herb layers of $1 \mathrm{~m} \times 1 \mathrm{~m}$. In tree layer, the species, number and $D B H$ values of all trees with $D B H \geq 5 \mathrm{~cm}$ were measured; In shrub layer, the species, number and $D B H$ values of all trees with $D B H<5 \mathrm{~cm}$ were measured. In herb layer, the species, number and heights of all herbs were measured (Fang et al., 2004; Fang et al., 2009; Wei et al., 2017).

\section{Data analysis}

Plant species diversity was analyzed and measured using general-purpose indexes (Leinster and Cobbold, 2012; Wei et al., 2017), including species richness index ( $S$; Eq. 1), Shannon-Wiener diversity index $(H ; E q .2)$, Simpson diversity index $(P ; E q .3)$ and Pielou evenness index (E; Eq. 4).

$$
\begin{gathered}
S=\text { the number of plant species in sample plot } \\
H=-\sum_{i=1}^{S}\left(P_{i} \times \ln P_{i}\right) \\
P=1-\sum_{i=1}^{s}\left(P_{i} \times P_{i}\right) \\
E=H / \ln S
\end{gathered}
$$

$P_{i}$ refers to the ratio between importance value of the i-th species and total importance value in sample plot. The importance value of tree layer or shrub layer $=$ (relative dominance + relative density + relative frequency) $/ 3$, the importance value of herb layer $=($ relative dominance + relative density + relative frequency $) / 3$.

In the data analysis process, SPSS 17.0 software (Chinese version) and method of one-way analysis of variance and significance test was used. 


\section{Results}

\section{Species composition of tree layer}

As shown in Table 1, the number of plant species in tree layer can be ranked as sample plot near $5.0 \mathrm{~m}$ scenic road corridor>wildwood area>sample plot near $2.5 \mathrm{~m}$ scenic road corridor; the number of plants in tree layer can be ranked as sample plot near $2.5 \mathrm{~m}$ scenic road corridor>wildwood area>sample plot near $5.0 \mathrm{~m}$ scenic road corridor; the mean DBH of plants in tree layer can be ranked as wildwood area $>$ sample plot near $2.5 \mathrm{~m}$ scenic road corridor>sample plot near $5.0 \mathrm{~m}$ scenic road corridor.

Table 1. Species, individual number and mean DBH of trees in wildwood area, sample plot near $5.0 \mathrm{~m}$ scenic road corridor and sample plot near $2.5 \mathrm{~m}$ scenic road corridor

\begin{tabular}{|c|c|c|c|c|c|c|}
\hline \multirow[t]{2}{*}{ Tree name } & \multicolumn{2}{|c|}{ Wildwood area } & \multicolumn{2}{|c|}{$\begin{array}{c}\text { Sample plot near } 2.5 \\
\text { m scenic road } \\
\text { corridor }\end{array}$} & \multicolumn{2}{|c|}{$\begin{array}{c}\text { Sample plot near } 5.0 \\
\text { m scenic road } \\
\text { corridor }\end{array}$} \\
\hline & $\begin{array}{l}\text { Plants } \\
\text { number }\end{array}$ & $\begin{array}{l}\text { Average } \\
D B H / c m\end{array}$ & $\begin{array}{l}\text { Plants } \\
\text { number }\end{array}$ & $\begin{array}{l}\text { Average } \\
D B H / c m\end{array}$ & $\begin{array}{c}\text { Plants } \\
\text { number }\end{array}$ & $\begin{array}{l}\text { Average } \\
D B H / c m\end{array}$ \\
\hline Pinus densiflora & 201 & 10.06 & 338 & 10.57 & 109 & 11.83 \\
\hline Quercus variabilis & 174 & 10.26 & 253 & 10.52 & 80 & 10.05 \\
\hline Pinus thunbergii & 45 & 12.27 & & & 33 & 13.45 \\
\hline Quercus mongolica & 37 & 15.08 & 14 & 13.79 & 27 & 10.74 \\
\hline Quercus hopeiensis & 20 & 6.55 & & & & \\
\hline Quercus fangshanensis & 12 & 13.75 & 1 & 10.00 & 7 & 10.00 \\
\hline Albizia kalkora & 8 & 5.00 & 11 & 10.18 & 22 & 8.36 \\
\hline Quercus acutissima & 5 & 5.80 & & & 30 & 6.50 \\
\hline Sorbus alnifolia & 4 & 5.00 & & & 4 & 10.25 \\
\hline Cerasus serrulata & 2 & 5.55 & & & & \\
\hline Pistacia chinensis & 1 & 5.00 & 24 & 6.62 & 2 & 8.00 \\
\hline Lauraceae. obtusiloba & 1 & 5.00 & & & 17 & 5.35 \\
\hline Salix matsudana & 1 & 5.00 & & & 3 & 7.00 \\
\hline Malus baccata & 1 & 5.00 & & & 1 & 5.00 \\
\hline Diospyros lotus & & & 2 & 6.50 & 1 & 6.00 \\
\hline Robinia pseudoacacia & & & 1 & 15.00 & 5 & 7.40 \\
\hline Rhus chinensis & & & & & 56 & 7.21 \\
\hline Larix kaempferi & & & & & 21 & 15.26 \\
\hline Ailanthus altissima & & & & & 8 & 9.00 \\
\hline Symplocos paniculata & & & & & 4 & 5.00 \\
\hline Alnus Sibirica & & & & & 3 & 9.33 \\
\hline Catalpa bungei & & & & & 2 & 20.00 \\
\hline Celtis koraiensis & & & & & 1 & 5.00 \\
\hline Pterocarya stenoptera & & & & & 1 & 5.00 \\
\hline Hovenia acerba & & & & & 1 & 16.00 \\
\hline Fraxinus rhynchophylla & & & & & 1 & 5.00 \\
\hline $\begin{array}{l}\text { Cerasus serrulata var. } \\
\text { pubescens }\end{array}$ & & & & & 1 & 8.00 \\
\hline Amorpha fruticosa & & & & & 1 & 5.00 \\
\hline Total & 512 & 10.67 & 644 & 10.46 & 441 & 10.18 \\
\hline
\end{tabular}




\section{Species composition of shrub layer}

As shown in Table 2, the number of plant species in shrub layer can be ranked as sample plot near $5.0 \mathrm{~m}$ scenic road corridor>wildwood area>sample plot near $2.5 \mathrm{~m}$ scenic road corridor; the individual number of low- $D B H$ shrubs can be ranked as sample plot near $2.5 \mathrm{~m}$ scenic road corridor>sample plot near $5.0 \mathrm{~m}$ scenic road corridor $>$ wildwood area; the individual number of high- $D B H$ shrubs can be ranked as wildwood area>sample plot near $5.0 \mathrm{~m}$ scenic road corridor>sample plot near $2.5 \mathrm{~m}$ scenic road corridor.

Table 2. Species, individual number of shrubs in wildwood area, sample plot near $2.5 \mathrm{~m}$ scenic road corridor and sample plot near $5.0 \mathrm{~m}$ scenic road corridor

\begin{tabular}{|c|c|c|c|c|c|c|}
\hline \multirow[b]{2}{*}{ Shrub name } & \multicolumn{2}{|c|}{ Wildwood area } & \multicolumn{2}{|c|}{$\begin{array}{c}\text { Sample plot near } 2.5 \\
\text { m scenic road corridor }\end{array}$} & \multicolumn{2}{|c|}{$\begin{array}{l}\text { Sample plot near } 5.0 \\
\text { m scenic road corridor }\end{array}$} \\
\hline & $\begin{array}{c}D B H<2.5 \\
\mathrm{~cm}\end{array}$ & $\begin{array}{c}2.5 \mathrm{~cm} \leq \\
D B H<5 \\
\mathrm{~cm}\end{array}$ & $\begin{array}{c}D B H<2.5 \\
\mathrm{~cm}\end{array}$ & $\begin{array}{c}2.5 \mathrm{~cm} \leq \\
D B H<5 \\
\quad \mathrm{~cm}\end{array}$ & $\begin{array}{c}D B H<2.5 \\
\mathrm{~cm}\end{array}$ & $\begin{array}{c}2.5 \mathrm{~cm} \leq \\
D B H<5 \\
\mathrm{~cm}\end{array}$ \\
\hline Indigofera kirilowii & 147 & & 372 & & 89 & \\
\hline Quercus variabilis & 154 & 43 & 209 & 56 & 81 & 19 \\
\hline Quercus mongolica & 97 & 14 & 106 & 5 & 29 & 3 \\
\hline Cerasus glandulosa & 37 & & 106 & 1 & 71 & 1 \\
\hline Rhus chinensis & 16 & & 29 & 1 & 147 & 20 \\
\hline Lauraceae. obtusiloba & 12 & 1 & & & 104 & 44 \\
\hline Quercus hopeiensis & 96 & 47 & & & & \\
\hline Leptopus chinensis & 22 & & 100 & 17 & 2 & \\
\hline Pinus densiflora & 22 & 25 & 37 & 36 & 6 & 3 \\
\hline Lespedeza bicolor & 34 & & 65 & & 21 & \\
\hline Albizia kalkora & 37 & 9 & 21 & 1 & 43 & 7 \\
\hline Kalopanax septemlobus & 17 & & & & 80 & 6 \\
\hline Quercus acutissima & 21 & 5 & 4 & 1 & 39 & 21 \\
\hline Euonymus phellomanus & 52 & 6 & 19 & 1 & 7 & \\
\hline Grewia biloba & 1 & & 68 & & 13 & \\
\hline Symplocos paniculata & 12 & 1 & 11 & 4 & 29 & 12 \\
\hline Diospyros lotus & 5 & & 5 & 1 & 54 & \\
\hline Robinia pseudoacacia & 15 & & 27 & 1 & 17 & 2 \\
\hline Ailanthus altissima & 18 & & 6 & & 35 & 1 \\
\hline Pinus thunbergii & 26 & 13 & & & 11 & 6 \\
\hline Zanthoxylum schinifolium & 32 & & 13 & & 5 & \\
\hline Euonymus alatus & 8 & & 13 & & 14 & 3 \\
\hline Celastrus orbiculatus & 8 & & 22 & & & \\
\hline Ligustrum sinense & 2 & & 7 & & 17 & 2 \\
\hline Pistacia chinensis & 14 & 2 & 9 & 1 & & \\
\hline Amorpha fruticosa & 4 & & 9 & & 10 & \\
\hline Quercus fangshanensis & 8 & 2 & 2 & 1 & 4 & 2 \\
\hline $\begin{array}{c}\text { Cerasus serrulata var. } \\
\text { pubescens }\end{array}$ & 6 & & & & 8 & \\
\hline Rosa multiflora & & & 7 & & 7 & \\
\hline
\end{tabular}




\begin{tabular}{|c|c|c|c|c|c|c|}
\hline Sorbus alnifolia & 9 & 1 & & & 3 & 1 \\
\hline Celastrus flagellaris & 3 & & & & 9 & \\
\hline Ulmus pumila & & & 6 & 5 & & \\
\hline Fraxinus rhynchophylla & 4 & & 5 & & & 1 \\
\hline Ulmus macrocarpa & & & & & 8 & \\
\hline Ampelopsis humulifolia & & & 3 & & 3 & \\
\hline Hibiscus syriacus & & & & & 4 & \\
\hline Catalpa bungei & & & & & 4 & \\
\hline Deutzia grandiflora & & & 3 & & & \\
\hline Salix matsudana & 1 & 1 & & & & 1 \\
\hline Hovenia dulcis & & & & & 1 & 1 \\
\hline Vitis amurensis & & & & & 2 & \\
\hline Cerasus serrulata & 2 & & & & & \\
\hline Celtis koraiensis & & & 1 & & & \\
\hline Pterocarya stenoptera & & & & & & 1 \\
\hline Malus baccata & & & 1 & & & \\
\hline Ziziphus jujuba var. spinosa & & & 1 & & & \\
\hline Total & 936 & 170 & 1292 & 133 & 983 & 157 \\
\hline
\end{tabular}

\section{Species diversity}

As shown in Figure 1A1-1A3, the species richness index, Shannon-Wiener diversity index and Simpson diversity index of plants in tree layer can be ranked as sample plot near $5.0 \mathrm{~m}$ scenic road corridor $>$ wildwood area $>$ sample plot near $2.5 \mathrm{~m}$ scenic road corridor $(P<0.05)$. However, the Pielou evenness index is ranked as sample plot near $5.0 \mathrm{~m}$ scenic road corridor>sample plot near $2.5 \mathrm{~m}$ scenic road corridor $>$ wildwood area $(P<0.05)$, as shown in Figure 1A4.

The species richness index, Shannon-Wiener diversity index, Simpson diversity index and Pielou evenness index of plant community in shrub layer are ranked as sample plot near $5.0 \mathrm{~m}$ scenic road corridor>sample plot near $2.5 \mathrm{~m}$ scenic road corridor>wildwood area (see Fig. 1B1-1B4).

The species richness index, Shannon-Wiener diversity index, Simpson diversity index and Pielou evenness index of plant community in herb layer are ranked as sample plot near $5.0 \mathrm{~m}$ scenic road corridor>wildwood area>sample plot near $2.5 \mathrm{~m}$ scenic road corridor (see Fig. 1C1-1C4).

\section{Discussion}

According to the investigation in Kunyu mountain national nature reserve of China, it can be known that compared with wildwood area, the mean $\mathrm{DBH}$ of tree layer decreases with the increase of width of scenic road corridor. The edge effect of shrub layer can be balanced by increasing the individual number of low-DBH shrubs and decreasing the number of high-DBH shrubs. Moreover, the edge effect of $2.5 \mathrm{~m}$ scenic road corridor than that of $5.0 \mathrm{~m}$ scenic road corridor.

In tree layer, the four indexes all showed as follows: sample plot near $5.0 \mathrm{~m}$ scenic road corridor was significantly higher than the sample plot near $2.5 \mathrm{~m}$ scenic road corridor and wildwood area. 

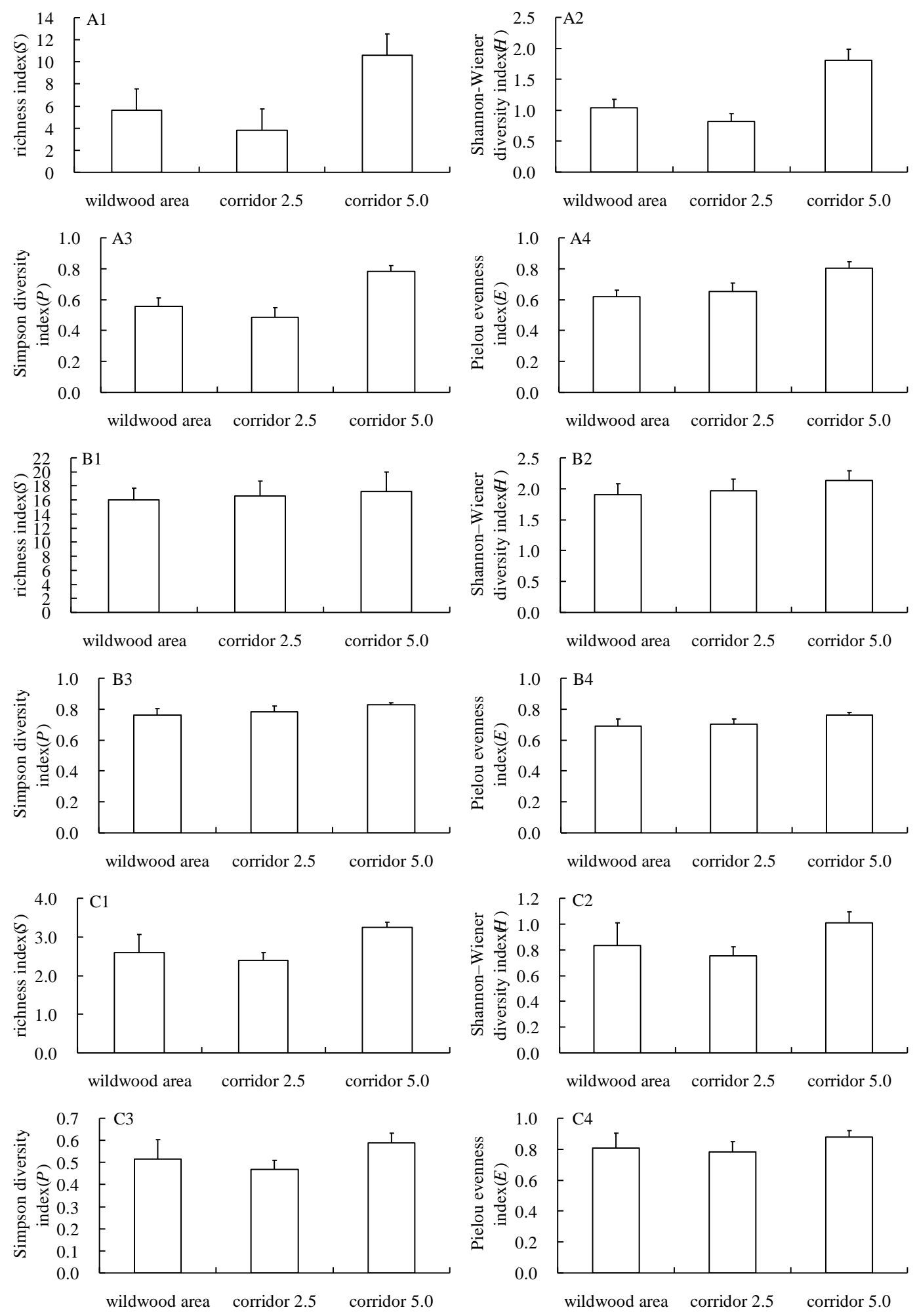

Figure 1. The richness index (1), Shannon-Wiener diversity index (2), Simpson diversity index

(3) and Pielou evenness index (4) for the tree layer (A), shrub layer (B) and herb layer in wildwood area, sample plot near $2.5 \mathrm{~m}$ scenic road corridor and sample plot near $5.0 \mathrm{~m}$ scenic road corridor in Kunyu Mountain (average + standard error). Corridor 2.5: sample plot near $2.5 \mathrm{~m}$ scenic road corridor; corridor 5.0: sample plot near $5.0 \mathrm{~m}$ scenic road corridor 
In shrub layer, the four indexes abovementioned can be ranked as sample plot near $5.0 \mathrm{~m}$ scenic road corridor>sample plot near $2.5 \mathrm{~m}$ scenic road corridor>wildwood area. In herb layer, the four indexes can be ranked as sample plot near $5.0 \mathrm{~m}$ scenic road corridor>wildwood area>sample plot near $2.5 \mathrm{~m}$ scenic road corridor. This study shows that the upper trees in forest plant community of Kunyu Mountain are less sensitive to edge effect compared with understory plants, which is inconsistent with the results of study on Cryptomeria fortunei plantation in Zhougong mountain of Western Sichuan province (Wang et al., 2016).

Researches have shown that edge effect influences the richness and density of evergreen broad-leaf forest ( $\mathrm{Li}$ et al., 2008), and forest edge effect is positive for extrinsic plant seed invasion (Lin and Cao, 2009). The influence of forest road on species diversity index only reaches into the plant community which is $5 \mathrm{~m}$ near road (Watkins et al., 2003), while a narrow corridor $(<4 \mathrm{~m})$ will cause decrease of Pinus koraiensis growth level (Wang et al., 2003).

\section{Conclusion}

This study shows that two scenic road corridors $(2.5 \mathrm{~m}$ and $5.0 \mathrm{~m})$ have opposite effects on forest plant community in Kunyu Mountain of China. The $2.5 \mathrm{~m}$ scenic road corridor exerts an inhibition effect on the species composition and diversity of plants in Kunyu mountain national nature reserve, however, $5.0 \mathrm{~m}$ scenic road corridor has a promoting effect. We suggest that we can continue to study the two road corridors in Kunyu Mountain, especially the corridor width to study the physiological and biochemical indexes such as growth, development and reproduction of plants.

Acknowledgements. Funded by the Fund of Shandong Provincial Key Laboratory of Water and Soil Conservation and Environmental Protection, Linyi University, No STKF201603.

\section{REFERENCES}

[1] Chen, L. D., Xu, J. Y., Fu, B. J., Lu, Y. H. (2004): Quantitative assessment of patch edge effects and its ecological implications. - Acta Ecologica Sinica 24: 1827-1832 [in Chinese].

[2] Du, N., Wang, Q., Guo, W. H., Wang, R. Q. (2007): Ecological characteristics of typical plant communities in Kunyu Mountain. - Chinese Journal of Ecology 26: 151-158 [in Chinese].

[3] Fang, J. Y., Shen, Z. H., Tang, Z. Y., Wang, Z. H. (2004): The protocol for the survey plan for plant species diversity of China's Mountains. - Biodiversity Science 12: 5-9 [in Chinese].

[4] Fang, J. Y., Wang, X. P., Shen, Z. H., Tang, Z. Y., He, J. S., Yu, D., Jiang, Y., Wang, Z. H., Zheng, C. Y., Zhu, J. L., Guo, Z. D. (2009): Methods and protocols for plant community inventory. - Biodiversity Science 17: 533-548 [in Chinese].

[5] García, J. D. D., Arévalo, J. R., Fernández-Palacios, J. M. (2007): Road edge effect on the abundance of the lizard Gallotia galloti, (Sauria: Lacertidae) in two Canary Islands forests. - Biodiversity and Conservation 16: 2949-2963.

[6] Leinster, T., Cobbold, C. A. (2012): Measuring diversity: the importance of species similarity. - Ecology 93: 477-489. 
[7] Li, M. H., Song, R. S., Jiang, Y. F., Zhao, G. F., Fu, H. L., Zheng, Y. M., Yu, M. J. (2008): Plant diversity in the six evergreen broad-leaved forest fragments in East China. Chinese Journal of Ecology 28: 1137-1146 [in Chinese].

[8] Lian, Z. M., Yu, G. Z. (2000): Edge effect and biodiversity. - Biodiversity Science 8: 120-125 [in Chinese].

[9] Lin, L. X., Cao, M. (2009): Edge effects on soil seed banks and understory vegetation in subtropical and tropical forests in Yunnan, SW China. - Forest Ecology and Management 257: 1344-1352.

[10] Liu, Y. G., Wang, Q., Wang, J. (2012): Landscape pattern and patch stability in Jiuzhaigou Nature Reserve. - Journal of Northeast Forestry University 40(4): 31-33 [in Chinese].

[11] Ma, W. Z., Liu, W. Y., Yang, L. P., Yang, G. P. (2008): Edge effects on epiphytes in montane moist evergreen broad-leaved forest. - Biodiversity Science 16: 245-254 [in Chinese].

[12] Naidoo, R., Kilian, J. W., Preez, P. D., Beytell, P., Aschenborn, O., Taylor, R. D., StuartHill, G. (2018): Evaluating the effectiveness of local- and regional-scale wildlife corridors using quantitative metrics of functional connectivity. - Biological Conservation 217: 96-103.

[13] Su, X. F., Yuan, J. F., Hu, Z. G., Xu, G. F., Yu, M. J. (2014): Edge effect of the plant community structure on land-bridge islands in the Thousand Island Lake. - Chinese Journal of Applied Ecology 25: 77-84 [in Chinese].

[14] Sun, Q., Lu, J. B., Wu, J. G., Zhang, F. F. (2008): Effects of island area on plant species distribution and conservation implications in the Thousand Island Lake region. Biodiversity Science 16: 1-7 [in Chinese].

[15] Tian, C., Yang, X. B., Liu, Y. (2011): Edge effect and its impacts on forest ecosystem: A review. - Chinese Journal of Applied Ecology 22: 2184-2192 [in Chinese].

[16] Velázquez, J., Gutiérrez, J., Hernando, A., García-Abril, A. (2017): Evaluating landscape connectivity in fragmented habitats: Cantabrian capercaillie (Tetrao urogallus cantabricus) in northern Spain. - Forest Ecology and Management 389: 59-67.

[17] Wang, D. Y., Hao, J. F., Li, Y., Qi, J. Q., Pei, Z. L., Huang, Y. J., Jiang, Q., Chen, Y. (2016): Examination of edge effects in a Cryptomeria fortunei plantation in Zhougong Mountain, western Sichuan. - Biodiversity Science 24: 940-947 [in Chinese].

[18] Wang, R. S., Ma, S. J. (1985): Edge effect and its application in economic ecology. Chinese Journal of Ecology 4(2): 38-42 [in Chinese].

[19] Wang, W. J., Zu, Y. G., Yang, F. J., Wang, H. M., Wang, F. (2003): Photosynthetic ecophysiological study on the growth of Korean pine (Pinus koraiensis) afforested by the edge-effect belt method. - Chinese Journal of Ecology 23: 2318-2326 [in Chinese].

[20] Watkins, R. Z., Chen, J. Q., Pickens, J., Brosofske, K. D. (2003): Effects of forest roads on understory plants in a managed hardwood landscape. - Conservation Biology 17: 411419.

[21] Wei, J. J., Gao, Y., Zhao, W. G., Liu, J. (2017): Hillside topographic pattern of shrub and herb diversity of forest in Mount tai of China. - Journal of Environmental Protection and Ecology 18: 571-580.

[22] Wu, Y. N., Tao, J. P., Xi, W. M., Zhao, K., Hao, J. H. (2011): The edge effects on treeliana relationship in a secondary natural forest in Bawangling Nature Reserve, Hainan Island, China. - Acta Ecologica Sinica 31: 3054-3059 [in Chinese].

[23] Zhou, T., Peng, S. L., Lin, Z. G. (2009): Edge effect of road in Dinghushan forests. Chinese Journal of Ecology 28: 433-437 [in Chinese].

[24] Zhu, Q., Yu, K. J., Li, D. H. (2005): The width of ecological corridor in landscape planning. - Acta Ecologica Sinica 25: 2406-2412 [in Chinese]. 